\title{
SOCIAL REPRESENTATIONS OF HEALTH SURVEILLANCE AMONG WORKERS
}

\author{
Dirciara Barañano Souza ${ }^{1}$ \\ Clarice Maria Dall Agnol ${ }^{2}$
}

Souza DB, Dall'Agnol CM. Social representations of health surveillance among workers. Rev Latino-am Enfermagem 2008 maio-junho; 16(3):452-7.

This is a qualitative, exploratory-interpretative study, with the purpose of investigating the social representations of health surveillance among members of the National Health Surveillance Agency - ANVISA, in Rio Grande do Sul State. It was found that health surveillance is represented by subjects as a process that, despite the contradictions, is being constructed and lived in the job routine with signs of renovation of existing representations. Thus, health protection acquires a new understanding, deviating from the prevention limits that traditionally focus on disease in order to return to promotion itself. Also, the image of health police is displaced from punishment to health education, establishing links between normative and educative performance. Moreover, professionalism is based on responsibility and knowledge, and professional devaluation is anchored in the idea of exclusion. The results allow for an analysis of the elements that can be causing permanencies and influencing the movements of daily practice, being able to revert into a benefit for the construction of a professional profile.

DESCRIPTORS: health surveillance; international health regulation; health manpower; public policies in health

\section{REPRESENTACIONES SOCIALES DE TRABAJADORES ACERCA DE LA VIGILANCIA SANITARIA}

Estudio cualitativo, exploratorio-interpretativo con el objetivo de conocer las representaciones sociales de trabajadores acerca de la vigilancia sanitaria en la Agencia Nacional de Vigilancia Sanitaria - ANVISA, RS. Vigilancia sanitaria fue representada por los sujetos como un proceso, el cual, a pesar de las contradicciones viene siendo construido y vivenciado en el cotidiano profesional con signos de renovación frente a las ya existentes. Así la protección de la salud adquiere una nueva comprensión, que se aleja de los límites de prevención, los que tradicionalmente enfocan a la enfermedad, para dirigirla en base a la noción de promoción. De la misma forma, la imagen de policía sanitaria, pasa de punición para educación sanitaria, estableciendo los ejes entre el hacer normativo y educativo. Por otro lado, el profesionalismo se fundamenta en la responsabilidad y conocimiento y en la falta de valor profesional basado en la exclusión. Los resultados favorecen un análisis de los elementos que pueden estar ocasionando su permanencia e influyendo en la práctica cotidiana, para posiblemente volverse en un beneficio para la construcción del perfil profesional.

DESCRIPTORES: vigilancia sanitaria; regulación sanitaria internacional; recursos humanos en salud; políticas públicas en salud

\section{REPRESENTAÇÕES SOCIAIS SOBRE VIGILÂNCIA SANITÁRIA ENTRE TRABALHADORES}

Estudo qualitativo, exploratório-interpretativo, com o objetivo de conhecer as representações sociais sobre vigilância sanitária entre trabalhadores da Agência Nacional de Vigilância Sanitária - ANVISA, no Rio Grande do Sul. Verificou-se que vigilância sanitária é representada pelos sujeitos como um processo que, apesar das contradições, vem sendo construído e vivenciado no cotidiano da profissão, com sinais de renovação das representações existentes. Assim, proteção à saúde adquire novo entendimento, distanciando-se dos limites da prevenção que tradicionalmente focaliza a doença, para voltar-se à noção de promoção. Também, a imagem de polícia sanitária desloca-se da punição para a educação sanitária, estabelecendo os elos entre os fazeres normativo e educativo. Além disso, o profissionalismo assenta-se em responsabilidade e conhecimento, e a desvalorização profissional ancora-se na idéia de exclusão. Os resultados propiciam análise dos elementos que podem estar causando permanências e influenciando os movimentos da prática cotidiana, podendo reverter em benefício da construção de um perfil profissional.

DESCRITORES: vigilância sanitária; regulação sanitária internacional; recursos humanos em saúde; políticas públicas em saúde

${ }^{1}$ RN, M.Sc. in Nursing, e-mail: dirciara.cramer@anvisa.gov.br; ${ }^{2}$ Ph.D. in Nursing, Faculty, Rio Grande do Sul Federal University School of Nursing, Brazil, email: clarice@adufrgs.ufrgs.br 


\section{INTRODUCTION}

The registers of measures that signal the beginning of current health surveillance practices in harbors, airports, borders and customs (VISAPAF, in Portuguese), date back to 1348 , with the opening of the Venice Harbors. In Brazil, health surveillance practices gained prominence in 1808 with the arrival of the Royal Family. Historically, these actions were restricted to an inspection status, whose main task was to prevent the entrance of diseases and provide international guarantees to shipments and travelers ${ }^{(1)}$. In the contemporary scenario, the globalization of economy, commerce, production, circulation of vehicles and people triggers a reorganization of the practices and starts a debate about the topic at several social levels. Thus, with a view to development with social participation, the negotiation chain has been challenging the National Agency of Health surveillance (ANVISA), created in the late $1990^{(2)}$, to coordinate discussion strategies locally, regionally, nationally and internationally.

This study looked at social representations about health surveillance among workers from the Health surveillance Coordination in Harbors, Airports, Borders and Customs services in the State of Rio Grande do Sul, Brazil, considering their construction from the reified and consensual perspective, expressed in mechanisms of objectivation and anchorage. It is worth mentioning that, although "health surveillance actions constitute the oldest side of public health" ${ }^{\prime \prime)}$, it was not until the past decades that they became study themes. Studies mostly deal with their historical construction in the social-politicaleconomic setting, contextualizing them with social relationships of production and consumption ${ }^{(3-4)}$. In specialized VISAPAF literature, except for two studies (5-6), the absence of citation of who performs the sanitary control is signaled. There is also minimum information regarding the work process. This reveals a historical-cultural silencing of surveillance workers, which seems to transmit a feeling of devaluation for the actions developed by the group, which they understand and express on a daily basis. Is it possible to have health surveillance, or its history, without subjects? Who are the subjects responsible for health surveillance actions? How is the knowledge constructed and how is it manifested in daily practices?

In this perspective, the social representation concept permitted an analysis of these questions, since it is contrary to the subject epistemology or the object itself ${ }^{(7-8)}$. The investigation of VISAPAF workers' social representations regarding health surveillance also received attention. They integrate the cognitive and affective dimensions, which are structured on the social reality these subjects are inserted in. The assumption was to use, explicitly, when conducting the research, a knowledge modality generated through daily life communication, which has the practical goal of guiding behaviors in social situations. Hence, the approach was meant to consider the historical-socialcultural complexity VISAPAF was constructed in.

\section{METHODOLOGICAL PROCEDURES}

In this exploratory-interpretative study, a qualitative approach was adopted, using the theoretical concepts of Social Representations Theory. They constitute a vast field for studies intended to encompass the cognitive, affective and social dimensions ${ }^{(9)}$. As a complementary approach to Moscovici's theory, the perspective closest to the original propositions was adopted as a reference, led by Denise Jodelet, in Paris. This is explained because "this is the most used approach by researchers who intend to fully understand the representation of a given object by a given social set" ${ }^{(10)}$.

Site and Subjects

Three health surveillance centers were studied: Uruguaiana Bureau of Border Protection, Porto Alegre Air Harbor Bureau and Rio Grande Harbor Bureau, in conjunction with the Health surveillance Coordination of Harbors, Airports, Borders and Customs Services - CVSPAF of ANVISA, in Rio Grande do Sul. This Coordination runs eleven state bureaus and has a team composed of men and women from several professional categories with different educational backgrounds, ranging from elementary to higher education. All of them perform the same activities. For subject selection, as inclusion criteria, workers who performed inspection activities and manifested interest in talking about the study theme were preferred. Workers who were absent in the information collection period for diverse reasons (health leave, personal leave, vacations, etc) or did not want to participate during the selection phase were excluded. 
Information Collection and Analysis Procedures

Information collection took place between November, 2005 and June, 2006. To initiate the process of apprehending the constituent elements of the social representations, looking for the first notion of the research subject, the free word association technique was used as a first resource. In practice, this started with word calling, using the expression health surveillance to induce associations, with the purpose of identifying the VISAPAF workers' representations about health surveillance. The following question was asked: What are the three first words that come to your mind when you hear the expression health surveillance? Afterwards, they were asked to organize these words, pointing out the two most significant and/ or important terms. This procedure was performed with 44 workers. Of the 52 workers who represented the three bureaus involved, one exclusively performed administrative activities, two were on a medical leave and five did not want to participate. Through the software 2003 MS Excel, the participants' words were organized in frequency lists, in order of appearance of the three mentioned words and the importance attributed to them by the participants.

After that, the signifiers were further studied. They were obtained from the word calling test, through the associations or confrontations with the meanings explored from the reports obtained by the semistructured interviews. Taking into account the French studies' perspectives to reach the saturation rate of the interviewed subjects ${ }^{(11)}$, a number of 30 participants was obtained. They were chosen by the "snowball" technique. For each of the study fields, the first worker was randomly chosen and, at the end of the interview, the respondent was asked to indicate a colleague and so on, until reaching the planned number of interviews for each site. Whenever an indicated subject could not participate, the snowball process was repeated with a new indication. The differences in the workers' quantitative contingent in the three bureaus were respected when the thirty interviews were distributed. After a literal transcription of the recorded material, floating reading was performed so as to capture the contents for analysis, preparing the text to apprehend the themes and reach the central categories. It should be mentioned that, during the delimitation of the theme categories, the data obtained from the word calling test were pondered.

In accordance with some studies ${ }^{(12)}$, the themes, in their conception, come up as the core of the consciousness, based on experience. The thematic structure somewhat coincides with the work of objectifying the representations. Thus, the affective, cognitive and social elements that organize and make the theme emerge indicate the second important feature to understand the social representations, that is, anchorage.

Ethical Precautions

Research with human beings should comply with Resolution 196/96 by the National Council of Health (CNS) and other requirements ${ }^{(13)}$. Firstly, approval was requested from the CVSPAF/RS, with explanation of the research objectives, methodology and ethical precautions. Before data collection started, the project was approved by the Research Ethics Committee at Rio Grande do Sul Federal University, No. 2005427. Two copies of the Term of Consent were signed, one for the subject and one for the researchers. Regarding the audio recording of the interviews, the tapes were destroyed after transcription. The transcribed material should be stored for five years, starting when the findings are published. All participant subjects were assured that they would receive the findings after the study was complete. One of the ways of publishing this study is to insert it in Intravisa - Internal Information System, accessed only by ANVISA workers.

\section{PRESENTATION AND DISCUSSION OF THE FINDINGS}

The following theme categories appear from the data obtained through the word calling test and the interviews: Health Protection, Professional Identity and Sanitary Police: the link between normative actions and sanitary education. The interview technique permitted the conceptualization of the information obtained through the word calling test. This conceptualization, in turn, supported the organization of the called words, leading to the thematic categorization. They are shown next:

Health Protection

The health protection category is one of the objectivations of representations about health surveillance, anchored in elements from reality, such as prevention actions, quality of life of the population, hygiene, welfare and right to health. These themes 
were reinforced in the word association test, with special attention to health and prevention due to their higher frequency, order of appearance and importance attributed by the subjects. They were frequently mentioned in the three calling sequences. The transformation of the health surveillance idea into health protection, as a crystallized image these people will probably understand and transmit, , is anchored in the prevention theme. However, preventing acquires the meaning of controlling to prevent the disease from entering the country, directly connected with the notion of barrier as a shield. Thus, health is strongly shown in connection with the idea of disease and with the normative action of controlling the borders.

The discourse between VISAPAF actions and health care actions is disconnected. Hence, the workers need to construct a new understanding and concepts without deviating from the Public Health System perspectives. Nevertheless, it is important to point out that practices in this field of knowledge are not restricted to basic healthcare activities, according to the legal definition ${ }^{(2)}$. It is a specific area, given that it regulates and monitors the quality of health goods that will circulate, with national and international effects. Therefore, it exceeds geographic borders in terms of health risks and economic effects of its regulations. On the other hand, the expression health promotion is circulating timidly among the VISAPAF workers. This may indicate a changing movement in the representation about health surveillance, due to the fact that there is a possible displacement of the prevention focus. In the author's analysis ${ }^{(5)}$, health promotion connected to a protection proposal appeared as an ANVISA attempt to overcome the police-like feature of surveillance actions, which has been constructed over the years, and to establish new concepts to support the practices.

Professional Identity

This category was divided into two axes, which are the subcategories: professionalism and professional devaluation. When the VISAPAF workers refer to themselves and the health surveillance, they pay attention to knowledge and performance construction on a daily basis. They were not aware of this field of knowledge. In this study, the group of workers presents the conception of a job that is defined in practical terms as an organization of their points of view (learning), the object of their work and the instruments required to perform health surveillance actions. According to some authors ${ }^{(14)}$, the lack of an academic background and professional qualification in this public health area represents a hindrance to transform surveillance practices. In this construction, there is an association between health surveillance and the theme category professionalism, which is configured as the crystallization of the social representation of the subject, the materialization of what was abstract to the subjects, that is, through the VISAPAF workers' thought and discourse. This objectivation process "is based on the art of transforming a representation into a representation reality, transforming the word that substitutes the thing into the thing that substitutes the word" ${ }^{(8)}$. The analysis of the interviews shows that the representation of health surveillance is anchored in elements related to responsibility, safety, knowledge and work. Hence, the terms responsibility, work, safety and knowledge called in the word association test gained meaning, reinforcing the ideas and feelings that are organized as the image or concept of professionalism.

The notion of responsibility is extended to health problems that can occur as a consequence of failures in this surveillance process, to commitment to the population. Therefore, the pertinence is related to the ethical-legal complexities and implications of the problems that threaten health and life. Thus, responsibility constitutes a pivotal aspect to cope with the objects of health surveillance. In the workers' discourse, there is concern with responsibility for life, health, people's illness and death, given that they intervene in the objects subject to the health surveillance actions.

The work appears related to the need for a better specification of the object of surveillance, and appears to be directly associated with the idea of responsibility. The workers are in a movement, even unconsciously, of constructing and marking their activity space, based on what is specific in the profession. Thus, they seek to organize their activities and behavior so as to comply with the complexity of the objects involved in health surveillance, structuring requisites to sustain a professional profile ${ }^{(15)}$. Hence, there is a search for specific awareness of this surveillance, giving meaning to the knowledge theme. It is tightly related to the safety theme, that is, it means counting on a technical-scientific support that minimizes the insecurities coming from the complexity of the object. On the other hand, there is a professional devaluation image, which suggests a possible hindrance to innovate the practices, although 
these practices are regarded as necessary. This image is anchored in elements like exclusion, low income and professional insecurity. In the word calling test, expressions like low importance and low salaries stand out because they appear first and subjects rank them as the most important. The expression "action at the end" deserves attention. It was used to describe the VISAPAF activities. This expression suggests a symbolic load impregnated with values and feelings that diminish the subjects to a humble view of performers. This position can indicate the influence of the reified universe ${ }^{(8)}$ as repressive and coercive power that makes the subjects assume themselves as constituted. On the other hand, it is necessary to reflect about what it means to say that "maybe it is easy to think that a great deal of societies are constituted without us, without our intervention" (9).

The notion of exclusion unveils workers' hard feelings, because of their expectation that the profession would be consolidated and recognized after the Agency was created in 1999. However, they were not inserted in the Agency's career plan but in its special task force. The word "low importance" mentioned by the workers can be better understood. There is an installed conflict that leads to the duality between "old" and "new", which corresponds to the subjects of this study and the professionals admitted through examinations, who joined the Agency as specialists and analysts in 2004. In the discourse, there is a pre and post ANVISA period. The Agency appears as a landmark which made the workers seem redundant. Hence, in the same perspective of valuation of these public health professionals, this statement is meaningful: "these healthcare workers are often appointed as potential subjects to change and reformulate the practices and are often said to be a burden, a problem to be solved"(14). Thus, the professionals endure a moment of tension and insecurity, which is justified by the arrival of new professionals and by the fear that VISAPAF will decentralize power. Regarding this last tension, it stems from a wide array of relationships with previous experiences most of these workers experienced after the dismantling of INAMPS, ordered by the guidelines established by the Public Health System. The workers then felt that they were about to lose their identity. For them, it was a negative experience that incited them to connect the Public Health System with this idea, a possible reason that made them not perceive themselves as constituents of the System.
Sanitary Police: the link between normative actions and sanitary education

Since its origin, health surveillance has been acting with the support of norms, assuming a judging and punishing status ${ }^{(3,16)}$, which often causes some distance between its image and its health practice. The VISAPAF workers' memories and experiences, although connecting health surveillance with the idea of health, still provide elements associated with the solidness of police as repressive power. This stability is justified in the representations' dependence on the groups' memory, since "memory solidness impedes the representations to suffer sudden modifications, providing a certain dosage of independence from current happenings" ${ }^{(8)}$. Thus, in the notion of sanitary police, the objectivation of the representation about health surveillance appears and becomes real when produced socially by workers through anchorage elements: inspection, sanitary control, sanitary barrier, risk, power and sanitary education.

Legislation appears as the main guiding resource in VISAPAF actions, although some displacement of the notion of sanitary control is seen beyond legal matters. The fears and anxieties surrounding the idea of risk have revealed the beginning of a practice that tends to exceed the limitations standards impose. However, in the workers' consciousness, the legal orientation determines what should be controlled. Nevertheless, when the fear of the unknown is revealed, signaling lack of risk indicators in health surveillance, the workers made this control approach visible.

Sanitary inspection stands as the most powerful law enforcement when it comes to surveillance practices. When establishing a relationship between inspection and control, the literature understands that control is higher and therefore includes inspection, in line with the law. However, in the workers' perceptions, the notion of inspection encompasses surveillance itself, which, in turn, would lead to risk control. Thus, workers go beyond with the goal of checking compliance with norms, indicating something bigger that involves behavior, attitude and responsibility towards society. Inspection begins to be discussed along with education. Hence, there is a drawback. Only one seems likely to occur. Consequently, controversy surrounding inspecting and educating appears. This doubt seems to be related with the meaning given to the familiarization of these two terms. The workers' statements contain memory registers that associate inspection practices with 
punishing actions and educative practices with pleasant gestures of understanding, a partnership with the inspected. The understanding of what educating means, for some of them, rests on the request, the conversation with the inspected so as to correct irregularities. After all, inspection actions take place with some informality, like transmitting information (16). If the idea of education appears connected to positive things, this explains the difficulties in joining the inspector's action to the educator's action. Therefore, conflict among the workers emerged, revealing a moment of tension and implying that they are heading for transformations ${ }^{\left({ }^{(8)}\right.}$.

\section{CONCLUDING REMARKS}

Based on the study's initial questions regarding the existence of a history of health surveillance without subjects, it is concluded that the subjects themselves reveal this history and vice-versa. Therefore, they gain visibility. However, studying health surveillance, from the subjects' perspective,

\section{REFERENCES}

1. Costa EA, Rosenfeld S. Constituição da vigilância sanitária no Brasil. In: Rosenfeld S, organizadora. Fundamentos de vigilância sanitária. Rio de Janeiro (RJ): FIOCRUZ; 2000. p. 15-40.

2. Brasil. Lei no. 9. 782, de 26 de janeiro de 1999. Define o Sistema Nacional de Vigilância Sanitária, cria a Agência Nacional de Vigilância Sanitária, e dá outras providências. Diário Oficial [da] República Federativa do Brasil, Brasília, DF, 27 jan. 1999. Seção 1, p. 1. Brasil.

3. Costa EA. Vigilância sanitária: proteção e defesa da saúde. 2. ed. aumentada. São Paulo (SP): Sobravine, HUCITEC; 2004.

4. Souto AC. Saúde e política: a vigilância sanitária no Brasil. São Paulo (SP): Sobravine; 2004.

5. Nunes PRS. Formação/educação dos trabalhadores da VISAPAF/ANVISA/MS. Porto Alegre (RS). Faculdade de Educação, Universidade Federal do Rio Grande do Sul; 2004. 6. Rocha MVV. Riscos de saúde provenientes de contaminação microbiana nas aeronaves e sua percepção na visão dos trabalhadores da vigilância sanitária de aeroportos. [dissertação]. Porto Alegre (RS). Universidade Luterana do Brasil; 2004 was a challenge due to the voids in literature. Furthermore, there is the challenge of Social Representations Theory as a lens for the interpretations. Despite the range of this theory, the methodological possibilities are still in a phase of discovery. The researcher is supposed to lead a better construction, as stated by the author ${ }^{(10)}$. There is the possibility of visualizing the concepts that sustain the workers' representations, providing support to analyze the elements that may be causing permanencies and influence the movements of daily practices. It is important that the subjects adopt a critical posture, being able to (re)act. That is, they may assume the status of social constituents, both in the consensual and reified dimension, and also in the VISAPAF setting.

The theoretical construction in this research permits the opening of novel ways to improve the perception of workers' relationships with work, their practices and society. Furthermore, these findings may be turned into benefits to construct a professional profile, provided that they are established during a participative movement between the ANVISAInstitution and the VISAPAF workers.

7. Jodelet D. Representações sociais:um domínio em expansão. In: Jodelet $D$, organizadora. As representações sociais. Rio de Janeiro (RJ): EdUERG; 2001. p. 17-44.

8. Moscovici S. Representações sociais: investigações em psicologia social. Petrópolis (RJ): Vozes; 2003.

9. Moscovici S. La psychanalyse, son image et son public. Paris: PUF; 1961.

10. Sá CP de. A construção do objeto de pesquisa em representações sociais. Rio de Janeiro (RJ): EDUERJ; 1998. 11. Ghiglione R, Matalon B. O inquérito: teoria e prática. 3. ed. Lisboa: Celta; 1997.

12. Vignaux G. Cátegorisations et schématisations: dês arguments au discours. In: Dubois D. (Ed.). Sémantique et cognition. Paris: CNRS; 1991. p. 215-50.

13. Ministério da Saúde (BR). Diretrizes e normas técnicas regulamentadoras de pesquisa envolvendo seres humanos. Brasília (DF): Ministério da Saúde; 1996.

14. Garabotti V, Hennington EA, Selli L. A contribuição dos trabalhadores na consolidação dos serviços municipais de vigilância sanitária. Cad Saúde Pública 2006 maio; 22(5):1043-51.

15. Gomes AMT, Oliveira DC. Estudo da estrutura da representação social da autonomia profissional em enfermagem. Rev ESC Enfermagem USP 2005 janeiro; 39(2):145-53.

16. Fernandes MA, Freitas AP. Práticas de fiscalização e educação em vigilância sanitária. In: Alves MG. Vigilância sanitária: principais tecnologias de intervenção. Salvador: OPAS; 2005. p. 20-5. 